Journal of Agriculture and Food Sciences

Volume 19 Number 1, April 2021 pp 134-149
Chiemela, C. J., Nwangwu, K. N., Nzennwa, R. C., Chiemela, S.N., Ibe, J.C. and Asogwa, B.U.

\title{
PROFITABILITY OF ON AND OFF-SEASON PLANTAIN MARKETING IN NSUKKA LOCAL GOVERNMENT AREA, ENUGU STATE, NIGERIA
}

\author{
Chiemela, C. J., Nwangwu, K. N.*, Nzennwa, R. C., Chiemela, S.N., Ibe, J.C. and \\ Asogwa, B.U. \\ Department of Agricultural Economics, University of Nigeria Nsukka \\ *Correspondence Email: nnaemeka.nwangwu@unn.edu.ng
}

\begin{abstract}
The study analysed the profitability of plantain marketing during on and off season in Nsukka local government area of Enugu state, Nigeria. Samples of 60 respondents were randomly selected from four communities within Nsukka Local Government Area to describe the socioeconomic characteristics of plantain marketers, identity the marketing channel of distribution performed, estimate the profitability of plantain marketing in and off season, identify the problems hindering plantain marketing. Data were analysed using, descriptive statistics and cost and return. The result showed that $70 \%$ of the respondents were female, within the age bracket of 40-50 years, implying that female of this age range is likely to be more energetic and willing to take risks involved in plantain marketing. Majority of them were married (86.7\%) and (60\%) have post primary education. Majority (51.7\%) of the respondents claim that between January to March is the on-season period with gross margin of N17, 239 while (53.3\%) believe off- season is from July-September with gross margin of N23, 775. This shows that it is more profitable to market plantain off- season. Major constraints include seasonality of product, lack of finance, pest and diseases attack, product breakages, lack of market information, price fluctuation and poor access road while cost of transportation, deterioration of product and high market fees are seen as minor constraints. Based on the findings of the study the following recommendations were made; Storage facilities for plantain should be made available to ensure all year-round production, availability and accessibility of the product.
\end{abstract}

Keywords: Profitability, Marketing, Plantain, Nsukka, On and Off season

https://dx.doi.org/10.4314/jafs.v19i1.10

\section{INTRODUCTION}

Plantain (Musa paradisica) is a food crop believed to have the potential of mitigating the twin problems of food security and poverty; it plays a key role in the economy of many developing countries such as Nigeria. The origin of plantain is not clear but some scholar believes that Plantain was introduced by the Portuguese from India and Brazil to West-Central Africa before 3000 BC. (Roger, 2009). Available trade records and associated indices showed that Nigeria is 
Journal of Agriculture and Food Sciences

Volume 19 Number 1, April 2021 pp 134-149

Chiemela, C. J., Nwangwu, K. N., Nzennwa, R. C., Chiemela, S.N., Ibe, J.C. and Asogwa, B.U. one of the largest producers of plantain in the world (FAO, 2013). Nigeria is ranked first in Africa and fifth in the world producing 2,722,000 metric tons in 2011 (FAO, 2012).

Plantain is a seasonal, annual crop with relative short shelf life, and its Production in Nigeria is concentrated in humid lowland to upland tropical areas. It is grown mainly at the onset of rainy season and produce food within 7-8 months (IITA, 2009). It requires an average rainfall of $1,200 \mathrm{mmh}$ that is evenly distributed throughout the year to enable percolation in the soil as it does not do well in a waterlogged area. Planting with the first rains seems agronomically sound but not financially advantageous. Most farmers oftentimes plant at the onset of the rains, causing the market to be flooded with bunches months after planting (Iyabo, 2013). Planting in the middle of the rainy season is a better proposition as plantains will then be produced off-season and high prices will accrue from sales (Oladejo and Sanusi, 2008). Some plantain marketers buy plenty of plantain during surplus, process it into flour and store until when it becomes scarce and very costly and they sell it to make profit. According to Ariyo et al. (2013) profit in Plantain marketing involves the role of middlemen in passing plantain from the farms to the markets or from a particular market to another and selling them at a greater price. This movement of plantain is necessary as the product is made available in places where they are not.

One of the factors that have militated against efficient marketing of plantain according to Aina, (2010) has been thought towards ignorance on the part of marketers. This has led to low profitability as marketers are unaware of the particular period to make available transportation for movement of plantain to areas where they are needed. This has led to high post-harvest losses which are the major problems limiting the availability of plantain in the country and in the study area (Bayeri and Nwachukwu, 2003). Also, unavailability or ignorance of when to provide storage facility or subsidy for storage facilities according to Josiah (2014) has discouraged many marketers and farmers who would want to keep part of his produce till off-season so that profit could be enhanced.

However, majority of the agricultural studies in Nigeria highlighted other factor that has limited maximum profit in marketing of plantain. Akinyemi, (2010) pointed out that majority of plantain marketers still operate on a small scale which makes unit cost of plantain costly, high cost of transportation, seasonal price fluctuation, poor access road which has caused perishable goods such as plantain to spend so much time on transit. The work of Abiodun-Solanke, (2010) opined that inadequate knowledge of handling and processing of plantain into form which can last a 
Journal of Agriculture and Food Sciences

Volume 19 Number 1, April 2021 pp 134-149

Chiemela, C. J., Nwangwu, K. N., Nzennwa, R. C., long period has also led to wastages. Bayeri and Nwachukwu (2003) opined that most large farms are always located inside the forests, far away from road access, this makes the produce to stay on heaps for several days by the road side. This area of distribution, marketing and sale for profit has been void as there has been little work done on it; majority of work done has only been on production. Therefore, this study intends to fill the gap by estimating the profitability of plantain farmers both during on-season and off-season period. Specifically, the study also seeks to describe the socio-economic characteristics of plantain marketers, identify the marketing channel of distribution and marketing function performed and identify the problems hindering plantain marketing in the study area.

\section{MATERIALS AND METHOD}

Multistage sampling technique was used in drawing out the sample for the study. First, purposive sampling was employed in selecting four (4) communities within Nsukka Local Government Area which have major plantain market and plantain trading occurs in the markets frequently and the towns involved are; Nsukka town, Ibagwa-Ani, Eha-Alumona and Opi. The markets are Ogige main market in Nsukka town, Nkwo-Ibagwa in Ibagwa Ani, Ahor market in Eha-Alumona town and Afor-Opi market in Opi town. Sixty (60) plantain marketers from the four (4) markets were randomly selected, that is 15 respondents from each market, in order to have unbiased spread of respondents for the study. The data for this study was obtained from primary source. The data collected from the respondents was achieved using statistical tools such as descriptive statistics (frequency counts, percentages and means), gross margin analysis and the hypothesis was achieved using student T-test. Specifically, objective (i) and (ii) were achieved using descriptive statistics; objective (iii) was achieved using gross margin analysis, objective (iv) was achieved using Likert scale rating technique.

Model Specification: Gross margin analysis was used to estimate the profitability of plantain marketing in the study area, (objective three).

$$
\mathrm{GM}=\mathrm{TR}-\mathrm{TC} \text { and } \mathrm{TC}=\mathrm{TFC}+\mathrm{TVC}
$$

Where

$\mathrm{GM}=$ Gross margin 
Journal of Agriculture and Food Sciences

Volume 19 Number 1, April 2021 pp 134-149

Chiemela, C. J., Nwangwu, K. N., Nzennwa, R. C., $\mathrm{TR}=$ Total revenue (Price per bunch $\mathrm{x}$ number of bunches sold).

$\mathrm{TC}=$ Total cost

TFC $=$ Total fixed cost, which include building, rent, storage facilities

$\mathrm{TVC}=$ Total variable cost, which include; Cost of purchase, transport cost.

\section{Likert type scale rating}

Likert scale rating technique was used to analyse objective (IV) which is to identify the problems hindering plantain marketing in the study area and four-point scale was used as it does not give room for the respondents to be indifferent. The rating was in this order: strongly agree $(\mathrm{SA})=4$, agree $(A)=3$, disagree $(\mathrm{D})=2$, and strongly disagree $(\mathrm{SD})=1$. The mean score of the respondents based on the 4 - point scale was $4+3+2+1=10,10 / 4=2.50$. Using the interval scale of 0.05 , the upper limit cut-off point was $2.50+0.05=2.55$. The lower limit was $2.50-$ $0.05=2.45$. Based on these, any mean score below 2.45 (i.e., MS < 2.45) are regarded not important. Those between 2.45 and 2.55 were considered important (i.e., $2.45<\mathrm{MS}<2.55$ ). Mean score greater than 2.55 (MS > 2.55) are however considered very important.

\section{RESULTS AND DISCUSSION}

\section{Socio-economic characteristics}

The socioeconomic characteristics of plantain marketers studied were gender, age, marital status, household size, educational background, major occupation, and marketing experience. The result from Table 1revealed that $70 \%$ of the respondents were female while $30 \%$ were males. It is clear from the result that most of the plantain marketers in the study area are females. This finding corresponded with the result reported by Jatto et al. (2020), Aina (2012) and Mayokun and Fisayo (2010), they observed that greater percentage of rural women are involved in the trade of food stuff in Nigeria.

Table 1 indicates that majority (36.6\%) of the plantain marketers are within the age bracket of 41-50 years, followed by age range of 30-40 years (19.9\%). This is an indication that people whose age range between 30-50 years is in their active age and are more involved in plantain 
Journal of Agriculture and Food Sciences

Volume 19 Number 1, April 2021 pp 134-149

Chiemela, C. J., Nwangwu, K. N., Nzennwa, R. C., Chiemela, S.N., Ibe, J.C. and Asogwa, B.U. marketing in the study area. This may imply that people of this age range are likely to be more energetic and willing to take risks involved in plantain marketing.

The result in table 1 showed that majority of plantain marketers were married $86.7 \%$ while only $13.3 \%$ were single. The implication is that married people engage more in plantain marketing hence having greater number of labour force through their children and other members of the household who assist in the plantain enterprise. This implies also that plantain marketing is a reliable source of income for the upkeep of the family.

Table 1 also showed that majority (56.8\%) of the respondents have family size of 6-8 followed by $40 \%$ that have family size of $1-5$, while $3.3 \%$ claimed to have $9-11$. This fall in line with findings of Nse-Nelson (2016) that $54 \%$ of plantain marketers had household size between 6-10 persons. But this finding contradicts the work by Aina (2012) whose study showed that household size of the respondents shows that the highest range was between 1-4 persons (56\%) and the least was 8 persons and above (6.7\%). This may signify that plantain marketing is veritable means of income to cater for relatively large household size.

According to level of education attained by the respondents, the result revealed that a greater percentage (51.7\%) have secondary education. This conforms with the findings of Josiah (2014) who reported that $40 \%$ of plantain marketers has post primary education and also in line with Aina (2012) which revealed that a greater percentage (64\%) of his plantain marketers have post primary education. This finding contrasts with Aregbesola (2001), in which he estimated that most respondents had no formal education. The implication of this could be that plantain marketing is taking care of unemployment as more educated people are getting involved in the business.

Table 1 reveals that $58.3 \%$ of the respondents take plantain marketing business as their only major occupation while $41.7 \%$ combine marketing of other agricultural products with plantain marketing. This finding is not in line with Aina (2012 and Josiah (2014). This could be that marketers who dwell on plantain marketing as their major source of livelihood are more likely to use the best marketing channels being that they are not distracted with other business.

It was also showed that $(55 \%)$ of the respondents have marketing experience above 10 years as the highest while $45 \%$ of respondents who falls below 10 years of marketing experience. These 
Journal of Agriculture and Food Sciences

Volume 19 Number 1, April 2021 pp 134-149

Chiemela, C. J., Nwangwu, K. N., Nzennwa, R. C., Chiemela, S.N., Ibe, J.C. and Asogwa, B.U. tallies with work carried by Aina (2012) where he reveals that marketing experience of above 10 years $(41.3 \%)$ has the highest percentage. Nwaiwu (2012) stipulated that increased marketing experience help marketers adapt to new positively marketing strategies and also agrees that a greater number of years in experience would help one know various problems besetting plantain production likewise marketing. This implies that plantain marketing is stable, sustainable and dependable since people stayed for long period of years in the business. However, it is agreeable that the higher the experience the more efficient marketing is as there is enough knowledge on how to minimize cost to get better benefits.

\section{Marketing channels of plantain}

Figure 1, the plantain producer supplies to the processor and the movement continues to the wholesaler to the retailer and finally to the consumer. In this channel, there are three middlemen involved; they are the processor, wholesaler and retailer. Other alternative routes can be from producer to retailer and to the consumer. In some cases, middlemen are not involved and the producer sells directly to the final consumers. This depicts that plantain marketing in the study area is decentralized. It implies that the wholesaler and some retailers purchase their product directly from the farmers.

\section{Whom the respondents buy from}

Table 2 showed that $28.3 \%$ of the respondents buy from retailer, $26.7 \%$ buys from local assembler, 25\% buys from wholesaler, this according to Aina (2012) could be an indication that plantain enjoys high demand while $20 \%$ buy directly from farmers. This could mean that the marketers are sensitive to profit maximization.

\section{Whom the respondents sell to}

Table 3 showed that, higher percentages $(49.3 \%)$ of the respondent sell to consumers, while $31.7 \%$ sell to retailers and the remaining $18.3 \%$ sell to wholesaler. This according to Oladejo and Sanusi, (2008) may imply that majority (49.3\%) of the respondent are retailers, $31.7 \%$ are wholesaler while the remaining $18.3 \%$ are farm gate buyers. 
Journal of Agriculture and Food Sciences

Volume 19 Number 1, April 2021 pp 134-149

Chiemela, C. J., Nwangwu, K. N., Nzennwa, R. C., Chiemela, S.N., Ibe, J.C. and Asogwa, B.U.

\section{Profitability of plantain marketing In and Off season}

\section{The profitability of plantain during $\mathrm{ON}$ season}

From Table 4 it can be seen that $51.7 \%$ of respondent claim that between Januarys to March is the on-season period while $48.3 \%$ claimed on season is around October to December. From Table 5, it can be noted that other total variable cost incurred is $\$ 1,741.5$ and fixed cost is $\mathrm{Q} \times \mathrm{P}$ i.e. $65 \times 592.5=\$ 38,512.5$ therefore total cost incurred in on season is $\$ 38,512.5+1741.5=$ $\$ 40,254$. While total revenue generated is Quantity sold x selling price i.e., 65 x $884.5=\$ 57$, 493. Then gross margin is revenue - total cost $\$ 57,493-\$ 40,254=\$ 17,239$.

\section{Off season distribution of respondent}

Table 6 shows that $53.3 \%$ of the respondents believe off season is from July - September while $46.7 \%$ of the respondents believe that off season period is between April - June. Other total variable cost incurred is $\$ 1,702$ and fixed cost is $Q$ x P i.e. 63.4 x $760=\$ 48,184$ therefore total cost incurred in on-season is N48, $184+1702=\mathrm{N} 49,886$ (Table 7). While total revenue generated is Quantity sold x selling price i.e., 63.4 x $1135=\$ 71$, 959. Then gross margin is revenue - total cost i.e., $\$ 71,959-\$ 49,886=\$ 22,073$.

From the result, it can be seen that it is more profitable to market plantain off season as its profit were $\mathrm{N} 22,073$ than to market plantain during on-season as profit were $\$ 17,239$ giving a difference of $\$ 4,834$ in the study area.

\section{Hypothesis testing}

The result presented on table 8 showed that $\mathrm{T}$ calculated value of 0.71 is less than $\mathrm{T}$ tabulated value of 1.98. Since the calculated $\mathrm{T}$ value was less than the tabulated $\mathrm{T}$ value, it therefore depicts that the difference between the profitability of plantain marketing on and off season was not significant. In order to confirm this, the probability value herein of 0.48 was higher than the maximum probability value for significance of 0.05 . This means that the difference between the in season and off season was not significant. Based on the above, the study accepts the null hypothesis which states that there is no significant difference in the profitability of plantain marketing in on and off season. 
Journal of Agriculture and Food Sciences

Volume 19 Number 1, April 2021 pp 134-149

\section{Constraints of plantain marketing}

Irrespective of all benefits derived from the profitability of plantain marketing, there is however inherent challenges that constraints effective marketing. The result showed the distribution of the various constraints the plantain marketers face during marketing of their products.

From Table 9, it can be seen that seasonality having mean score of 3.5 is the main factor pointed out by the respondents, this also could be attributed to changes in profitability between on and off season of plantain marketing, other major constraints having a mean score of 3.2 include; lack of finance which according to Jatto et al. (2020) opined that lack of fund is the major challenge for small scale marketing, lack of market information, price fluctuation and Poor access road all having a mean score of 3.2, while product breakages and pest and diseases have a mean score of 3.1 and 3.0 respectively, other minor constraints with their respective mean scores are deterioration of product has a mean score of 1.9 and both high cost of transportation and high market fees have a mean score of 1.7 .

\section{CONCLUSION}

Plantain (Musa paradisica) is a food crop believed to have the potential of mitigating the twin problems of food security and poverty and it plays a key role in the economy of many developing countries such as Nigeria. Efforts should be made by government, private sector and all stake holders to ensure continued availability and accessibility of plantain at all season to ensure increased earnings, improvement of socioeconomic life of both the farmers and traders so as to increase food security, eliminate hunger and create employment opportunity. Marketing of plantain and other agricultural produce should not be neglected as they serve as means of livelihood. An increase in production requires a commensurable increase in effort at marketing. This will avert spoilage and positively influence distribution. Problems associated with plantain marketing mostly are those of variable cost like high cost of transportation and high cost of plantain. Another major problem is lack of credit supply or access which may have been necessitated by the low level of education and lack of knowledge on how to access such. Based on these, the following recommendations are made; Government, international organization such as FAQ, public and private stakeholders should put hands on deck in ensuring that adequate irrigation and storage facilities for plantain production so there will be all year-round production 
Journal of Agriculture and Food Sciences

Volume 19 Number 1, April 2021 pp 134-149

Chiemela, C. J., Nwangwu, K. N., Nzennwa, R. C., Chiemela, S.N., Ibe, J.C. and Asogwa, B.U. and availability and accessibility of the plantain. This will reduce the seasonality problem of the product. There should be adequate means of communication among marketers in the marketing channels so as to create good marketing information between marketers and consumers.

Private individuals, cooperative and shareholders should help in building of good and accessible roads to reduce the problems of high transportation charge and cost. Investors and other stakeholders should invest in the provision of transportation facilities that will enhance transportation so as to reduce quantitative and qualitative losses and make plantain available where and when need. This will help to reduce post-harvest losses, deterioration in quality and quantity. Plantain marketers should organize themselves into cooperatives so as to reap the benefit of large economic of scale. These whole recommendations if properly implemented will help to boost the profitability of plantain in the study areas as well as increase income of the farmers and marketers. 
Journal of Agriculture and Food Sciences

Volume 19 Number 1, April 2021 pp 134-149
Chiemela, C. J., Nwangwu, K. N., Nzennwa, R. C., Chiemela, S.N., Ibe, J.C. and Asogwa, B.U.

\section{REFERENCES}

Abiodun-Solanke, A.O and Falade, K.O. (2010). A review of the uses and methods of processing banana and plantain into storable food products. Journal of Agriculture and Social Science, 9(2). https://doi.org/10.4314/jard.v9i2.66815

Aina O.S., Ajijola S., Bappah M.T., Ibrahim I. and Musa I.A (2012). Economic Analysis of Plantain Marketing in Odigbo Local Government Area of Ondo State, Nigeria. Global Advanced Research Journal of Agricultural Science, 1(5): 104-109

Akinyemi, S.O.S., Aiyelaagbe, I.O.O., and Akyeanipong, E. (2010). Plantain (Musa spp.) cultivation in Nigeria: A review of its production, marketing and research in the last two decades. Production of Banana and Plantain in Africa. 211-218. https://doi.org/10.17660/ActaHortic.2010.879.19

Aregbesola, G.O. (2001). An Analysis of plantain marketing in Akure North and South Local Government Areas of Ondo State. A Project Report, Department of Agricultural Extension and Management, Federal College of Agriculture, Akure, Nigeria.

Ariyo, O. C., Ariyo, M. O., Okelola, O. E., Omodona, S., Akesode, H. A. and Akanni,. R. J. (2013). Profitability analysis of plantain marketing in kaduna metropolis, Kaduna state Nigeria. Journal of Agriculture and Social Research, 13(1):21-30. www.ajol.info/index.php/jasr/article/view/112533

Bayeri, K. P. and Nwachukwu, I. (2003). Storage methods influenced occurrence and severity of crown rot and anthracnose diseases on plantain (Musa spp. ABB) fruits during storage and post storage. p.201-204. In : A.S. Fasina, A. O. Olufolaji and V.C.Umeh (eds.), Proceeding of the 21st Annual Conference of the Horticultural Society of Nigeria, Lagos.

FAO 2012. Commodity data, Country rankings, Retrieved 02/16/2012, fromhttp://mongabay.com/commodities/data/category/1-Production/1-Crops/489Plantains/51-Production+\%28tonnes\%29

FAO, 2013. Food and Agriculture Organization of the United Nations. Crop yield. Retrieved December 22, 2020, from http://faostat.fao.org/site/567/DesktopDefault.aspx?PageID=567\#ancor

International Institute of Tropical Agriculture (2009). Annual report. Retrieved April 2016, from https://www.google.com/url?sa=t\&source=web\&rct=j\&url=https://www.iita.org/wp content/uploads/2016/04/Annual-Report-2009

Iyabo. B. A, Omobowale. A. O, Sulaiman. A.Y and Kemisola. O. A. (2013). Plantain value chain mapping in southwestern Nigeria. Journal of Economics and Sustainable Development, 4:137-145 .

Jatto, K.A., Adeoye, A.S., Abegunrin, O.O., Oke, O.O., Eniola, O. and Smart, M. (2020). Analysis of Plantain Marketing in Afijio Local Government Area of Oyo State, Nigeria. Journal of Agriculture and Food Environment,7(2): 26-34.

Josiah P.G., (2014). Analysis of the profitability of plantain firming in Orhionwon local Government area of Edo state, Nigeria. B.Sc Project submitted to the Department of Agricultural Economics and Extension Services, University of Benin, Nigeria.

Mayokun, K.A. and Fisayo, T.A. (2010). Factors affecting the improved technologies in plantain and banana cultivation by farmers in Ondo State. Nigerian Journal of Agricultural Extension 2(5):16 - 20. 
Journal of Agriculture and Food Sciences

Volume 19 Number 1, April 2021 pp 134-149
Chiemela, C. J., Nwangwu, K. N., Nzennwa, R. C., Chiemela, S.N., Ibe, J.C. and Asogwa, B.U.

Nwaiwu, I. U., Eze, C., Aniaechi, E. C. and Osuagwu, C. O. (2012). Problems and prospects of large scale plantain and banana (Musa spp.) production in Abia State. Nigeria. International Journal of Basic and Applied Sciences, 1(4): 322-327

Oladejo, J. A. and Sanusi, W. A. 2008. Marketing analysis of plantain in Owo and Ose LocalGovernment Area of Ondo State, Nigeria. International Journal of Agricultural Economics and Rural Development, 7(2):60 - 67.

Roger, B. (2009). Bananas and plantains in Africa: Re-interpreting the linguistic evidence. Ethnobotany Research and Applications. https://doi.org/10.17348/era.7.0.363-380 
Journal of Agriculture and Food Sciences

Volume 19 Number 1, April 2021 pp 134-149
Chiemela, C. J., Nwangwu, K. N., Nzennwa, R. C., Chiemela, S.N., Ibe, J.C. and Asogwa, B.U.

Table 1: Distribution of Respondents by Socioeconomic Characteristics.

\begin{tabular}{|c|c|c|}
\hline $\begin{array}{l}\text { Socio-economic } \\
\text { characteristics }\end{array}$ & Frequency & Percentage (\%) \\
\hline \multicolumn{3}{|l|}{ Gender } \\
\hline Female & 42 & 70 \\
\hline Male & 18 & 30 \\
\hline Total & 60 & 100 \\
\hline \multicolumn{3}{|l|}{ Age (years) } \\
\hline Below 30 & 8 & 13.3 \\
\hline $30-40$ & 12 & 19.9 \\
\hline $41-50$ & 22 & 36.6 \\
\hline $51-60$ & 10 & 16.7 \\
\hline 61.80 & 8 & 13.5 \\
\hline Total & 60 & 100 \\
\hline \multicolumn{3}{|l|}{ Marital status } \\
\hline Single & 8 & 13.3 \\
\hline Married & 52 & 86.7 \\
\hline Total & 60 & 100 \\
\hline \multicolumn{3}{|l|}{ Household size } \\
\hline $1-5$ & 24 & 40 \\
\hline $6-8$ & 34 & 56.7 \\
\hline $9-11$ & 2 & 3.3 \\
\hline Total & 60 & 100 \\
\hline \multicolumn{3}{|l|}{ Educational status } \\
\hline No formal education & 10 & 16.7 \\
\hline Primary school & 14 & 23.3 \\
\hline Secondary school & 31 & 51.7 \\
\hline High institution & 5 & 8.3 \\
\hline Total & 60 & 100 \\
\hline \multicolumn{3}{|l|}{ Major occupation } \\
\hline $\begin{array}{l}\text { Trading and plantain } \\
\text { marketing business }\end{array}$ & 25 & 41.7 \\
\hline $\begin{array}{l}\text { Plantain marketing business } \\
\text { only }\end{array}$ & 35 & 58.3 \\
\hline Total & 60 & 100 \\
\hline $\begin{array}{l}\text { Marketing } \\
\text { (Years) }\end{array}$ & & \\
\hline Below 10 & 27 & 45 \\
\hline $10-20$ & 32 & 55 \\
\hline $20-30$ & 1 & 1.7 \\
\hline Total & 60 & 100 \\
\hline
\end{tabular}


Journal of Agriculture and Food Sciences

Volume 19 Number 1, April 2021 pp 134-149
Chiemela, C. J., Nwangwu, K. N., Nzennwa, R. C., Chiemela, S.N., Ibe, J.C. and Asogwa, B.U.

Table 2: Distribution of respondent by whom they buy from

\begin{tabular}{lll}
\hline Channels & Frequency & Percentage (\%) \\
\hline From farmers & 12 & 20.0 \\
From wholesaler & 15 & 25.0 \\
From local assembler & 16 & 26.7 \\
From retailer & 17 & 28.3 \\
Total & $\mathbf{6 0}$ & $\mathbf{1 0 0}$ \\
\hline
\end{tabular}

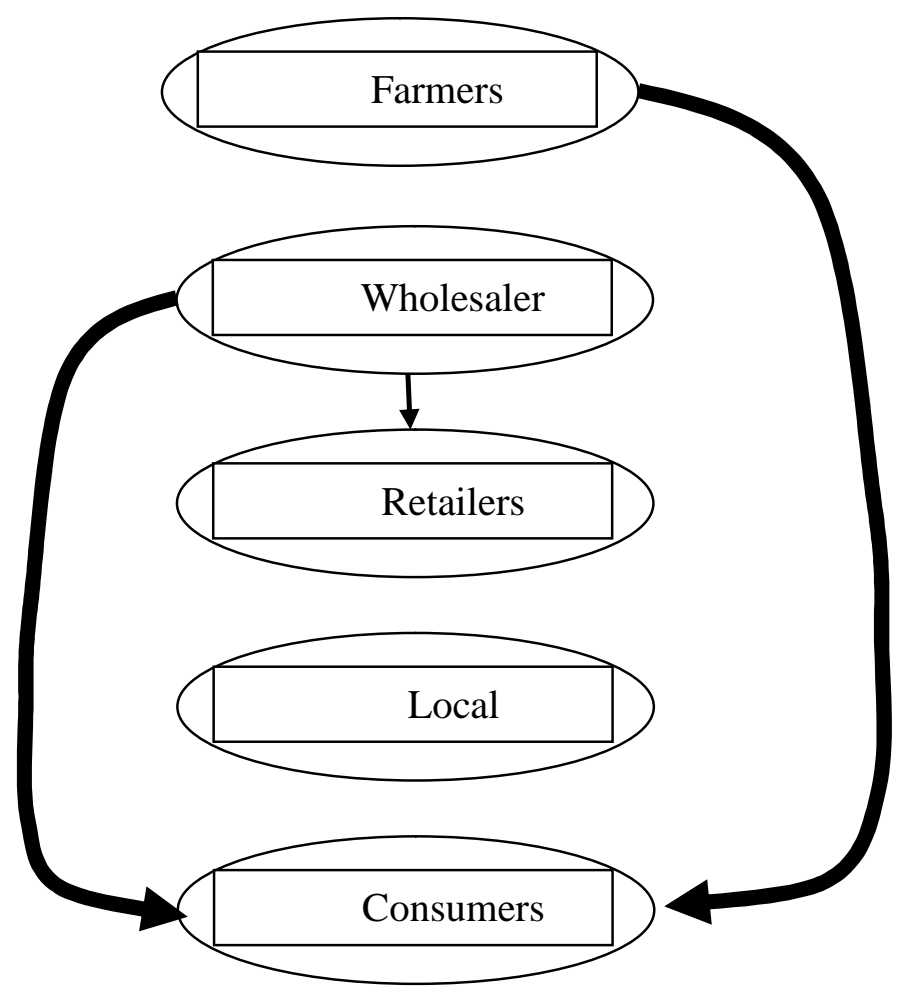

Figure 1: Schematic representation of plantain marketing channel in Nsukka LGA of Enugu State. 
Journal of Agriculture and Food Sciences

Volume 19 Number 1, April 2021 pp 134-149
Chiemela, C. J., Nwangwu, K. N., Nzennwa, R. C. Chiemela, S.N., Ibe, J.C. and Asogwa, B.U.

\begin{tabular}{lll}
\multicolumn{3}{c}{ Table 3: Distribution of respondents by whom they sell to } \\
\hline Channels & Frequency & Percentage (\%) \\
\hline Consumer & 30 & 49.3 \\
Wholesaler & 11 & 18.3 \\
Retailer & 19 & 31.7 \\
Total & $\mathbf{6 0}$ & $\mathbf{1 0 0}$ \\
\hline
\end{tabular}

Table 4: Distribution of respondent for on-season period

\begin{tabular}{lll}
\hline On season & Frequency & Percentage (\%) \\
\hline October - December & 31 & 51.7 \\
January - March & 29 & 48.3 \\
Total & $\mathbf{6 0}$ & $\mathbf{1 0 0}$ \\
\hline
\end{tabular}

Table 5: The profitability of plantain during ON season

Items (bunches per month)

Amount

Total (N)

\section{Revenue}

Quantity sold

$65 \mathrm{x}$

Total selling price

884.5

Total revenue

$57,493.5$

Variable cost

Qty bought

$65 \mathrm{x}$

Total cost price

592.5

$38,512.5$

Total purchase cost

368.5

Transportation

407

Storage cost

206

Trading material

196

Tax

132

Rent

432

Total variable cost

40, 254

Gross margin $=($ TR-TVC $)$ 
Journal of Agriculture and Food Sciences

Volume 19 Number 1, April 2021 pp 134-149
Chiemela, C. J., Nwangwu, K. N., Nzennwa, R. C., Chiemela, S.N., Ibe, J.C. and Asogwa, B.U.

Table 6: Distribution of respondent for off season period

\begin{tabular}{lll}
\hline Off season & Frequency & Percentage (\%) \\
\hline April - June & 28 & 46.7 \\
July - September & 32 & 53.3 \\
Total & $\mathbf{6 0}$ & $\mathbf{1 0 0}$ \\
\hline
\end{tabular}

Table 7: The profitability of plantain during Off season

\begin{tabular}{lll}
\hline Items (bunches per month) & Amount & Total (N) \\
\hline Revenue & & \\
Quantity sold & $63.4 \mathrm{X}$ & \\
Total selling price & 1,135 & 71.959 \\
Total revenue & $63.4 \mathrm{x}$ & \\
Variable cost & 760 & \\
Qty bought & 421 & $\mathbf{4 8 , 1 8 4}$ \\
Total cost price & 384 & \\
Total purchase cost & 267 & \\
Transportation & 178 & \\
Storage cost & 326 & \\
Trading material & 126 & \\
Rent & & $\mathbf{4 9 , 8 8 6}$ \\
Tax & & $\mathbf{N 2 2 , 0 7 3}$ \\
Total variable cost & & \\
Gross margin = (TR-TVC) & & \\
\hline
\end{tabular}


Journal of Agriculture and Food Sciences Volume 19 Number 1, April 2021 pp 134-149

Table 8: Hypothesis result

\begin{tabular}{llllll}
\hline Season & Mean & SD & T calculated & Df & P value \\
\hline On season & 17575.87 & 29465.79 & 0.71 & 118 & 0.48 \\
Off season & 22402.33 & 43399.20 & & & \\
\hline
\end{tabular}

Source: Field survey, 2017; $\mathrm{T}$ tabulated $=1.98$

Table 9: Mean distribution of respondents on constraints to plantain marketing

\begin{tabular}{lccl}
\hline Constraint & Mean score & Std dev. & Decision \\
\hline Lack of finance & 3.2 & 0.71 & major constraint \\
Seasonality of product & 3.5 & 0.54 & major constraint \\
High cost of transportation & 1.7 & 0.78 & minor constraint \\
Deterioration of product & 1.9 & 0.76 & minor constraint \\
Pest and diseases & 3.0 & 0.62 & major constraint \\
Product breakages & 3.1 & 0.52 & major constraint \\
Market information & 3.2 & 0.61 & major constraint \\
High market fees & 1.7 & 0.75 & minor constraint \\
Price fluctuation & 3.2 & 0.54 & major constraint \\
Poor access road & 3.2 & 0.48 & major constraint \\
\hline
\end{tabular}

